\title{
Second-generation products contribute substantially to the particle-phase organic material produced by $\beta$-caryophyllene ozonolysis
}

\author{
Y. J. Li ${ }^{1,2}$, Q. Chen ${ }^{3}$, M. I. Guzman ${ }^{3, *}$, C. K. Chan ${ }^{2,4}$, and S. T. Martin ${ }^{3,5}$ \\ ${ }^{1}$ Environmental Engineering Program, Hong Kong University of Science and Technology, Hong Kong, China \\ ${ }^{2}$ Division of Environment, Hong Kong University of Science and Technology, Hong Kong, China \\ ${ }^{3}$ School of Engineering and Applied Sciences, Harvard University, Cambridge, Massachusetts, USA \\ ${ }^{4}$ Department of Chemical and Biomolecular Engineering, Hong Kong University of Science and Technology, \\ Hong Kong, China \\ ${ }^{5}$ Department of Earth and Planetary Sciences, Harvard University, Cambridge, Massachusetts, USA \\ * now at: Department of Chemistry, University of Kentucky, Lexington, Kentucky, USA
}

Received: 9 July 2010 - Published in Atmos. Chem. Phys. Discuss.: 22 July 2010

Revised: 11 December 2010 - Accepted: 15 December 2010 - Published: 6 January 2011

\begin{abstract}
The production of secondary organic aerosol (SOA) by the dark ozonolysis of gas-phase $\beta$-caryophyllene was studied. The experiments were conducted in a continuous-flow environmental chamber for organic particle mass concentrations of 0.5 to $30 \mu \mathrm{g} \mathrm{m} \mathrm{m}^{-3}$ and with ozone in excess, thereby allowing the study of second-generation particle-phase products under atmospherically relevant conditions. The particle-phase products were characterized by an ultra-performance liquid chromatograph equipped with an electrospray ionization time-of-flight mass spectrometer (UPLC-ESI-ToF-MS). Fragmentation mass spectra were used for the structural elucidation of each product, and the structures were confirmed as consistent with the accurate $\mathrm{m} / \mathrm{z}$ values of the parent ions. In total, fifteen products were identified. Of these, three are reported for the first time. The structures showed that 9 out of 15 particle-phase products were second generation, including all three of the new products. The relative abundance of the second-generation products was approximately $90 \%$ by mass among the $15 \mathrm{ob}-$ served products. The O:C and $\mathrm{H}: \mathrm{C}$ elemental ratios of the 15 products ranged from 0.13 to 0.50 and from 1.43 to 1.60 , respectively. Fourteen of the products contained 3 to 5 oxygen atoms. A singular product, which was one of the three newly identified ones, had 7 oxygen atoms, including 1 carboxylic
\end{abstract}

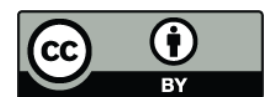

Correspondence to: S. T. Martin (scot_martin@harvard.edu) group, 2 carbonyl groups, and 3 hydroxyl groups. It was identified as 2, 3-dihydroxy-4-[2-(4-hydroxy-3-oxobutyl)3, 3-dimethylcyclobutyl]-4-oxobutanoic acid $\left(\mathrm{C}_{14} \mathrm{H}_{22} \mathrm{O}_{7}\right)$. The estimated saturation vapor pressure of this product is $3.3 \times 10^{-13} \mathrm{~Pa}$, making this product a candidate contributor to new particle formation in the atmosphere.

\section{Introduction}

The molecules produced by the oxidation of sesquiterpenes $\left(\mathrm{C}_{15} \mathrm{H}_{24}\right)$ have a high potential to form condensable products and contribute substantially to the secondary organic material of atmospheric particles, especially in areas of elevated biological emissions (Hoffmann et al., 1997; Griffin et al., 1999; Jaoui et al., 2003). The high particle-mass yields during sesquiterpene oxidation have led to suggestions that this family of molecules can make important contributions to total organic particle mass concentrations (Hoffmann et al., 1997; Jaoui et al., 2003; Ng et al., 2006), perhaps even the dominant contribution near sources such as in- and above-canopy of forests (e.g., contributing to new particle formation and dominating growth of fresh particles) (Martin et al., 2010). Compared to the more extensively studied monoterpenes $\left(\mathrm{C}_{10} \mathrm{H}_{16}\right)$ (Hallquist et al., 2009), sesquiterpenes have five additional carbon atoms. The longer carbon chain decreases the vapor pressures of the oxidation products

Published by Copernicus Publications on behalf of the European Geosciences Union. 
(Pankow and Asher, 2008). Sesquiterpenes also typically have more than one reactive double bond, thereby providing several points of potential molecular connections for the types of oxygenated organic functional groups that reduce vapor pressure. Under atmospheric conditions, the ozonolysis reactions of sesquiterpenes typically dominate compared to competing reaction pathways, such as those with hydroxyl or nitrate radicals (Shu and Atkinson, 1995). For endo-cyclic alkenes like many sesquiterpenes, ozonolysis reactions (1) favor the formation of carboxylic acid groups and (2) minimize the breaking of the carbon backbone structure (Kroll and Seinfeld, 2008). These reaction features both favor the formation of products that have lower vapor pressures compared to the reaction pathways of hydroxyl or nitrate radicals.

The sesquiterpene $\beta$-caryophyllene has received the most attention in the literature (Jaoui et al., 2003; Nguyen et al., 2009; Winterhalter et al., 2009). Its structure, which includes one endo-cyclic and one exo-cyclic double bond, is shown in Fig. 1a. It is emitted by many trees and agricultural plants (Duhl et al., 2008) and in some cases is the dominant sesquiterpene emission, such as for Citrus varieties (Ciccioli et al., 1999). Given its prevalence, several studies have focused on its role in the formation of secondary organic aerosol (SOA). The molecular products found in the particle phase following oxidation have been characterized, both for atmospheric sampling (Pio et al., 2001; Jaoui et al., 2007; Parshintsev et al., 2008) and in laboratory experiments (Griffin et al., 1999; Jaoui et al., 2003). A particlephase product ( $\beta$-caryophyllinic acid) first identified in the laboratory (Jaoui et al., 2003) was later found in the atmosphere (Jaoui et al., 2007) and subsequently used as a tracer of $\beta$-caryophyllene oxidation (Hu et al., 2008). A particular focus of laboratory studies has been SOA particle mass yield, defined as the particle mass concentration after reaction divided by the mass concentration of $\beta$-caryophyllene consumed (Grosjean et al., 1993; Hoffmann et al., 1997; Griffin et al., 1999; Jaoui et al., 2003; Lee et al., 2006; Ng et al., 2006). The reported yields have ranged from $40 \%$ (Jaoui et al., 2003) to 100\% (Hoffmann et al., 1997). The oxidation reaction mechanism has also been investigated, especially as related to first-generation products (Jaoui et al., 2003; Nguyen et al., 2009; Winterhalter et al., 2009). The contributions of different reaction pathways to particle mass yield have been analyzed using a kinetics-based approach (Nguyen et al., 2009).

First-generation products, some of which are illustrated in panel B of Fig. 1, are those resulting from the reaction of one double bond of $\beta$-caryophyllene (Jaoui et al., 2003; Winterhalter et al., 2009). An unreacted double bond remains in these products. Further reactions involving this second double bond produce second-generation products. Several examples are shown in panel $\mathrm{C}$ of Fig. 1. The examples selected for panels B and C of Fig. 1 are, by way of conclusion, the ones we detect and report in this study. Compared to their first-generation counterparts, the second-generation

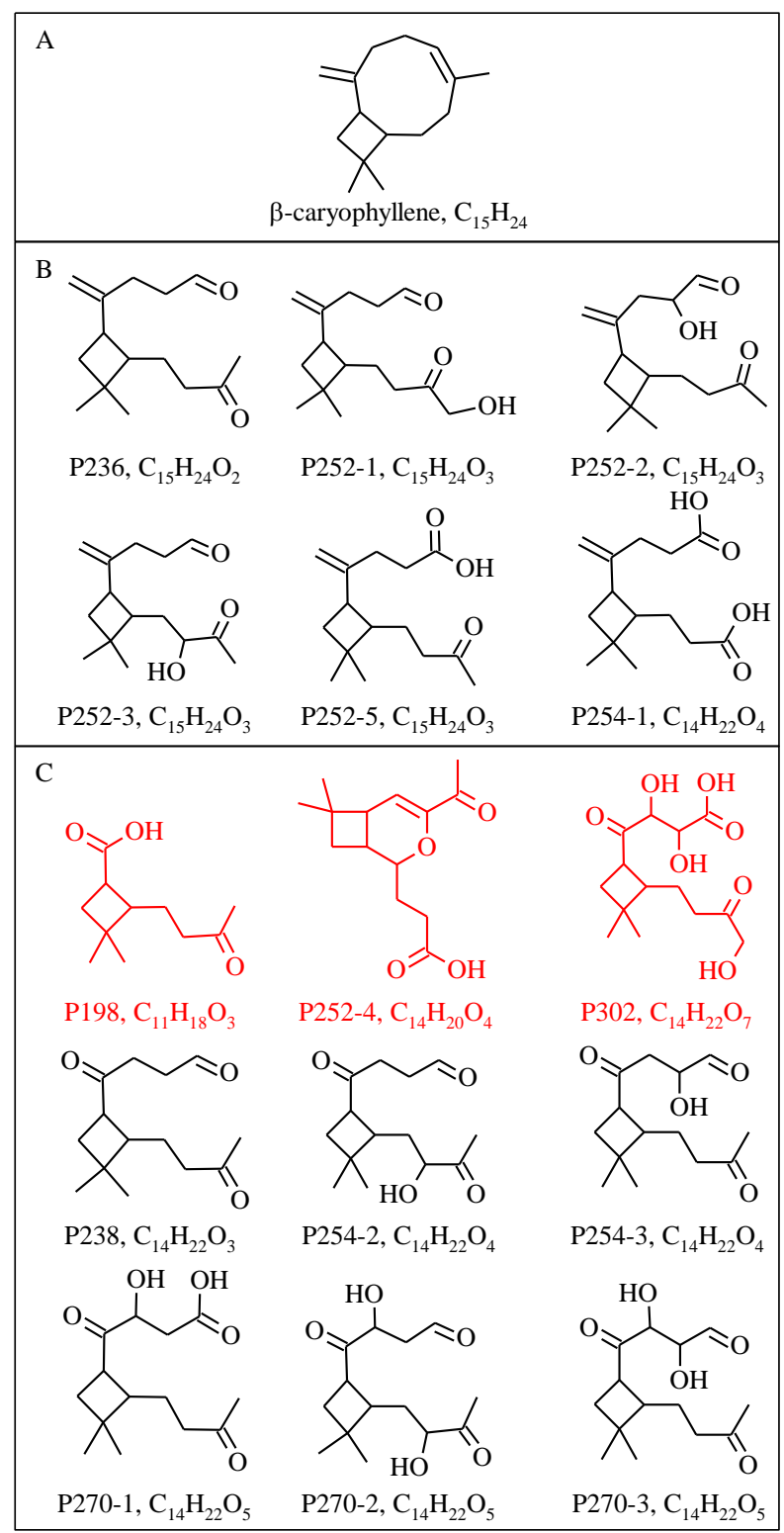

Fig. 1. Molecular structures of (A) $\beta$-caryophyllene, (B) detected first-generation ozonolysis products, and (C) detected secondgeneration ozonolysis products. The fifteen structures represented in panels $\mathrm{B}$ and $\mathrm{C}$ are found in the particles after ozonolysis. Three of them (viz. P198, P252-4, and P302) are reported herein for the first time and are highlighted in red. Label "Pxxx" represents a product $P$ having a nominal mass of $x x x$. Labels "Pxxx-1", "Pxxx2", and "Pxxx-3" denote distinct molecules (i.e., of different chromatographic retention times) that have the same nominal mass.

products are more oxygenated and therefore have lower saturation vapor pressures. They are therefore expected to make larger relative contributions to particle-phase organic mass concentrations. These oxygenated molecules on a partial molar basis also have greater hygroscopicity, contributing both to water uptake at elevated relative humidity $(\mathrm{RH})$ and cloud 
condensation nuclei (CCN) activity for supersaturated $\mathrm{RH}$ (Hartz et al., 2005; Asa-Awuku et al., 2009).

The formation rates of second-generation products, as well as the associated chemical mechanisms, have been little investigated. For the most part, laboratory studies have been conducted under ozone-limited conditions, meaning that the total concentration of double bonds associated with $\beta$-caryophyllene exceeded the stoichiometric ozone equivalence. Comprehensive product characterization was performed in several previous studies regarding $\beta$-caryophyllene ozonolysis. These studies, however, focused on first-generation products formed under conditions for which ozone concentrations were at approximately stoichiometric quantities with respect to reactions of the first double bond (Jaoui et al., 2003; Kanawati et al., 2008). In contrast, atmospheric ozone concentrations are in excess of the possible consumption by VOCs. Ozone concentrations range from 10 to $30 \mathrm{ppbv}$ at background sites (Fiore et al., 2003 ) to over $100 \mathrm{ppbv}$ in urban locations (Solomon et al., 2000). The concentrations of BVOCs, however, are normally less than $10 \mathrm{ppbv}$ in forested environments (Helmig et al., 1998). Ozone is also continuously renewed in the atmospheric column whereas VOC concentrations are limited by their surface emissions.

In the present study, experiments were conducted for the dark ozonolysis of $\beta$-caryophyllene in the continuous-flow Harvard Environmental Chamber (HEC) under conditions of excess ozone. The concentration of ozone was maintained constant by feedback control, and excess ozone facilitated the formation of second-generation oxidation products. Therefore, the conditions of the present study can be considered as ozone-rich compared to those of previous studies. An ultra-performance liquid chromatograph, coupled to an electrospray ionization time-of-flight mass spectrometer (UPLC-ESI-ToF-MS), was used to characterize the particlephase products. Products formed for conditions of excess ozone were elucidated, with a focus on second-generation products. Product volatilities and implications for particle formation and growth are discussed.

\section{Experimental}

\subsection{Chamber experiments}

The dark ozonolysis of $\beta$-caryophyllene was conducted in the Harvard Environmental Chamber (HEC) in a continuousflow steady-state mode. The HEC has been described previously (Shilling et al., 2008; King et al., 2009). For the experiments of this study, reaction conditions were $25^{\circ} \mathrm{C}$ and $40 \% \mathrm{RH}$, and seed particles of dry quasi-monodisperse ammonium sulfate having an electric mobility-equivalent diameter of $50 \mathrm{~nm}$ were used. The oxidation products of $\beta$-caryophyllene deposit on the surfaces of the seed particles and coat them. A liquid solution $(1: 2500, \mathrm{v} / \mathrm{v})$ of $\beta$-caryophyllene (Sigma-Aldrich, $\geq 98.5 \%$ ) in cyclohexane (Sigma-Aldrich, $\geq 99.9 \%$ ) was fed by a syringe pump into a gently warmed glass bulb. A flow of air swept the vapor into the chamber. Cyclohexane served as a scavenger of the $\mathrm{OH}$ radicals that were produced by some ozonolysis pathways. The concentration of $\beta$-caryophyllene in the chamber prior to reaction (i.e., before ozone injection) was confirmed by gas-phase hydrocarbon measurements using an Ionicon proton-transfer-reaction mass spectrometer (PTR-MS). The total flow rate through the chamber was $21.6 \mathrm{Lpm}$, corresponding to a mean residence time of $3.6 \mathrm{~h}$.

In a series of experiments (Table S1), the initial concentration of $\beta$-caryophyllene was varied from 1.7 to $46.4 \mathrm{ppbv}$ by adjusting the liquid injection rate from the syringe pump. The ozone concentration was set to 50,100, or $200 \mathrm{ppbv}$ and was maintained constant by feedback control. Because of the feedback control, the ozone concentrations refer to the excess ozone in addition to that consumed by the reactive chemistry. For example, the feedback control maintained an ozone concentration in $50 \mathrm{ppbv}$ (in excess) inside the chamber even as $46.4 \mathrm{ppbv} \beta$-caryophyllene (constantly supplied by syringe pump injection) was reacted. We focus on the results of experiments conducted at $50 \mathrm{ppbv}$ ozone concentration. The same products were observed in experiments conducted at 100 and $200 \mathrm{ppbv}$. The lifetime of $\beta$-caryophyllene against ozonolysis (i.e., first-generation reactions on the endo-cyclic double bond) was $70 \mathrm{~s}$ based on a bimolecular rate constant of $1.16 \pm 0.43 \times 10^{-14}$ molecule ${ }^{-1} \mathrm{~cm}^{3} \mathrm{~s}^{-1}$ (Shu and Atkinson, 1995). In turn, the average ozonolysis lifetime of the first-generation products was $7500 \mathrm{~s}$ based on an average rate constant of $1.1 \pm 0.4 \times 10^{-16}$ molecule ${ }^{-1} \mathrm{~cm}^{3} \mathrm{~s}^{-1}$ for the ozonolysis of the exo-cyclic double bond (Winterhalter et al., 2009). Compared to a mean residence time in the chamber of $3.6 \mathrm{~h}(12960 \mathrm{~s})$, a small steady-state concentration of $\beta$-caryophyllene was therefore expected in the chamber. In agreement, the PTR-MS measurements showed that less than $3 \%$ of the $\beta$-caryophyllene remained. Much of the reacted hydrocarbon exited the chamber in the particle phase. The organic particle mass concentrations were measured by an Aerodyne high-resolution time-of-flight aerosol mass spectrometer (HR-ToF-AMS) (DeCarlo et al., 2006; Shilling et al., 2008, 2009) and varied from 0.5 to $30 \mu \mathrm{g} \mathrm{m}^{-3}$ for the experimental conditions used.

\subsection{Sample collection and sample preparation}

Aerosol particles were collected for $4 \mathrm{hr}$ on quartz filters (Grade QM-A Circles, part number 1851-047, $47 \mathrm{~mm}$, Whatman) by sampling at $5 \mathrm{Lpm}$. Chamber conditions were at steady state during collection. In front of the filter setup, the particles passed through an ozone scrubber, which consisted of a diffusion tube having an outer annulus filled with ozone destruction catalyst (manganese dioxide/copper oxide, Carus Chemicals, Carulite 200). Samples were stored at $4{ }^{\circ} \mathrm{C}$ and analyzed by UPLC-ESI-ToF-MS within three days. Three 
consecutive 4-h samples were collected for each experimental condition.

For sample preparation for analysis by UPLC-ESI-ToFMS, a modified procedure of Glasius et al. (1999) and Gao et al. (2004) was followed. The filters were extracted with a 1:4 (v/v) mixture of HPLC grade acetonitrile $\left(\mathrm{CH}_{3} \mathrm{CN}\right)$ and dichloromethane in an ultrasonic bath for $15 \mathrm{~min}$. Filter debris was removed by passing the extract through a syringe filter (Spartan, part number 10463100, $13 \mathrm{~mm}, 0.2 \mu \mathrm{m}$, Whatman). The filtered extract of $5 \mathrm{~mL}$ was purged with a gentle flow of ultrapure nitrogen to a volume of less than $100 \mu \mathrm{L}$ and then reconstituted with $1 \mathrm{~mL}$ of $0.1 \%(\mathrm{v} / \mathrm{v})$ formic acid in a mixture of 80:20 (v/v) ultrapure $\mathrm{H}_{2} \mathrm{O}$ and HPLC grade methanol $(\mathrm{MeOH})$. The reconstituted solution was passed through a solid-phase extraction (SPE) cartridge (AccuBOND II, part number 188-1310, ODS-C18, $100 \mathrm{mg}$, $1 \mathrm{~mL}$, Agilent), which had been preconditioned by $2 \mathrm{~mL}$ $\mathrm{MeOH}$ and $2 \mathrm{~mL} \mathrm{H}_{2} \mathrm{O}$. Inorganic solute (i.e., ammonium sulfate) was removed by washing the SPE cartridges with $1 \mathrm{~mL} \mathrm{H}_{2} \mathrm{O}$. The organic compounds were eluted from the cartridges by $1 \mathrm{~mL} \mathrm{MeOH}$. A $100-\mu \mathrm{L}$ volume of $(48 \mu \mathrm{M})$ azelaic acid solution was added as an internal standard.

\subsection{UPLC-ESI-ToF-MS analysis}

Samples were analyzed by an ultra performance liquid chromatograph (UPLC; Acquity/LCT Premier XE, Waters Micromass, MassLynx 4.1 software) equipped with an electrospray ionization (ESI) interface and coupled to an orthogonal-acceleration time-of-flight mass spectrometer (ToF-MS). The chromatographic conditions are listed in Table S2, including the injection volume, the chromatographic column, the mobile phases, the eluent gradient, and the flow rate. Blank runs with solvent alone and runs with filter blanks both confirmed that the peaks in the chromatograms were not due to artifacts or reactions occurring during sample preparation. The conditions for the operation of the mass spectrometer (i.e., the ESI capillary voltage, the aperture-1 voltage of the ion optics, and so forth) are listed in Table S3 for three modes of ToF-MS measurements.

The three modes included a first directed to the determination of the accurate mass of the parent ion and hence its molecular formula, a second to the fragmentation of the parent ion for structure determination, and a third to the semiquantification of the products. The recorded mass spectra were corrected for background by subtraction of the baseline mass spectra recorded near the chromatographic peaks. In the accurate-mass mode, the ToF-MS spectral resolution was $>12000$, as defined by $m / \Delta m$ where $m$ is the $m / z$ value of a singly charged ion and $\Delta m$ is the full width at half maximum of the ion peak. Quasi-molecular ions $\left([\mathrm{M}-\mathrm{H}]^{-}\right.$in ESI- and $[\mathrm{M}+\mathrm{H}]^{+}$in ESI+ modes) as well as adducts with formic acid $\left([\mathrm{M}+\mathrm{HCOOH}-\mathrm{H}]^{-}\right.$, ESImode), sodium formate $\left([\mathrm{M}+\mathrm{NaOOCH}-\mathrm{H}]^{-}, \mathrm{ESI}-\right.$ mode $)$, sodium $\left([\mathrm{M}+\mathrm{Na}]^{+}\right.$, ESI+ mode), and methanol+sodium
$\left(\left[\mathrm{M}+\mathrm{CH}_{3} \mathrm{OH}+\mathrm{Na}\right]^{+}, \mathrm{ESI}+\right.$ mode) were used for redundant determination of the molecular formulas of the products, where $\mathrm{M}$ represents the analyte molecule. The same identification approach was used to confirm the empirical formulas of ion fragments. To further confirm the molecular formulas of the products, we substituted acetic acid for formic acid as the additive in the eluent and subsequently identified the acetate adducts $\left(\left[\mathrm{M}+\mathrm{NaOOCCH}_{3}-\mathrm{H}\right]^{-}\right.$, ESImode) (Table S4). For the mode of semi-quantification, known concentrations of pinic acid in ESI- analysis and pinonic acid in ESI+ analysis were used as the calibration compounds, meaning that product concentrations were expressed on pinic-acid or pinonic-acid equivalency basis in the ESI- and ESI+ modes, respectively.

\section{Results and discussion}

\subsection{Product identification}

\subsubsection{Molecular formulas of the products}

Figure 2 shows the chromatograms recorded in ESIand ESI+ modes for the particle-phase products of $\beta$ caryophyllene ozonolysis. In ESI- mode, products having acidic sites, such as carboxylic acids, are readily ionized via deprotonation to form $[\mathrm{M}-\mathrm{H}]^{-}$, while in ESI+ mode those having neutral functional groups, such as carbonyls are ionized via proton attachment to form $[\mathrm{M}+\mathrm{H}]^{+}$(Kanawati et al., 2008). There are 17 peaks labelled in panels A (ESI- mode) and B (ESI+ mode) of Fig. 2, representing 15 detected products. Depending on the functional groups present, some molecules can be ionized in both modes.

For each of the labelled products, the accurate $\mathrm{m} / \mathrm{z}$ values recorded for the quasi-molecular ions and their corresponding adduct ions are listed in Table 1. Based on the accurate mass, molecular formulas are deduced and are also listed in Table 1. The differences between measured and expected $\mathrm{m} / \mathrm{z}$ values are less than $5 \mathrm{mDa}$. A new finding compared to literature is that the product P252-4 has a molecular formula of $\mathrm{C}_{14} \mathrm{H}_{20} \mathrm{O}_{4}$ (accurate mass of 252.1362). Previous studies assigned a molecular formula of $\mathrm{C}_{15} \mathrm{H}_{24} \mathrm{O}_{3}$ to all isomers observed at a nominal mass of 252 (Jaoui et al., 2003; Winterhalter et al., 2009).

Figure 2 shows that at some retention times chromatographic peaks overlay on one another. Because the ordinate value of Fig. 2 is the sum of measured ion intensities, some deconvolution of the chromatograms is possible by examination of the $m / z$-resolved chromatograms, shown as extracted ion chromatograms (EICs) in Fig. S1. This additional information is also used by us for product identification.

\subsubsection{Structures of the products}

Fragmentation of molecular ions by use of increased instrument voltage yields mass spectra that are useful for inferring 
Table 1. Particle-phase products of the dark ozonolysis of $\beta$-caryophyllene, as detected by UPLC-ToF-MS with electrospray ionization (ESI). Retention times (rt) are listed. Measured and calculated mass-to-charge $(\mathrm{m} / \mathrm{z})$ values as well as their difference are shown for both quasi-molecular and adduct ions. Labels ESI- and ESI+ represent negative and positive modes, respectively, of electrospray ionization. Product label extenders " $x$ ", " $y$ ", and " $z$ " are as discussed in the caption of Fig. 2.

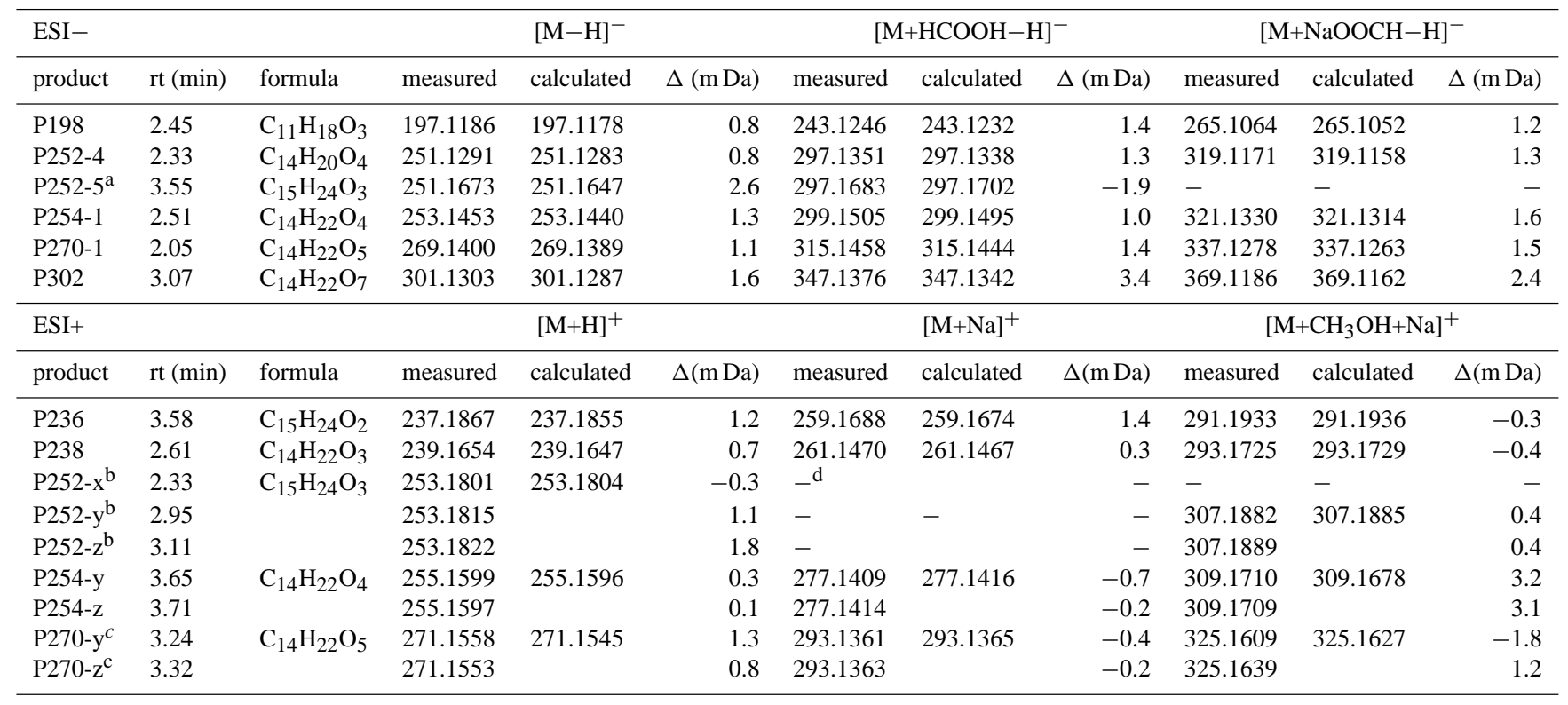

a see extracted ion chromatograms (EICs) in Fig. S1; ${ }^{\text {b }}$ fragmentation mass spectra did not allow unique assignments; P252-x in this table and Fig. 2 is tentatively assigned as P252-1; ${ }^{c}$ tentative assignments of P270-y to P270-2 and P270-z to P270-3 were made based on (1) the plausible fragmentation of P270-y to an ion peak at $m / z$ 239 and (2) the ionization of P270-z under ESI- mode (Fig. S1); ${ }^{\mathrm{d}}$ adduct ions were not observed.

the molecular structures of the products. Figure 3 shows the fragmentation mass spectra for three products not previously identified in the literature of $\beta$-caryophyllene ozonolysis. Figures S2 and S3 show the fragmentation mass spectra observed for products already reported in the literature. For ESI- ionization, fragments were observed at $-18 \mathrm{Da}$ (loss of $\mathrm{H}_{2} \mathrm{O}$ ), $-28 \mathrm{Da}$ (loss of $\mathrm{CO}$ or $\mathrm{C}_{2} \mathrm{H}_{4}$ ), $-30 \mathrm{Da}$ (loss of $\mathrm{CH}_{2} \mathrm{O}$ ), and $-44 \mathrm{Da}$ (loss of $\mathrm{CO}_{2}$, typically a carboxylic acid). For ESI+ ionization, fragments having consecutive losses of $-18 \mathrm{Da}$ (i.e., multiple $\mathrm{H}_{2} \mathrm{O}$ loss) were commonly observed. The observed fragmentation mass spectra are in general agreement with those of Kanawati et al. (2008), who used a triple quad-ToF instrument to study the products of $\beta$-caryophyllene ozonolysis, both by ESI ionization in negative mode and by atmospheric pressure chemical ionization in positive mode.

From the observed fragmentation mass spectra, we propose the 15 product structures illustrated in Fig. 1 and listed in Table 2. Twelve of the proposed structures (shown in black in panels $\mathrm{B}$ and $\mathrm{C}$ of Fig. 1) are either identical or isomeric with those reported in earlier studies (Jaoui et al., 2003; Kanawati et al., 2008; Winterhalter et al., 2009). In some cases, specific isomeric structures cannot be uniquely attributed to the chromatographic retention times because the fragmentation mass spectra recorded by our methods are sim- ilar within the isomer family. In these cases, families such as P252- $x$, P252- $y$, and P252- $z$ are used to label the chromatographic peaks in Fig. 2, where $x, y$, and $z$ are some permutation of 1,2 , and 3 with respect to the specific structures shown in Fig. 1. In comparison, Winterhalter et al. (2009) list six isomers with a molecular weight of 252, namely P2a, P2b, P4, P5, P8 and P9 in Table 5 of that study. Our observed fragmentation mass spectra indicate that the family P252- $x$, $\mathrm{P} 252-y$, and $\mathrm{P} 252-z$ corresponds to some permutation of P5, P8, and P9 (corresponding to P252-1, P252-3, and P252-2 of our study).

In Fig. 1c, three products P198, P252-4, and P302 not reported previously are shown in red. The mass spectra of these products, as well as the structures proposed to explain the spectra, are shown in Fig. 3. Of special note, product P302, which is 2, 3-dihydroxy-4-[2-(4-hydroxy-3-oxobutyl)-3, 3dimethylcyclobutyl]-4-oxobutanoic acid, contains 7 oxygen atoms and is the most oxygenated product reported to date for $\beta$-caryophyllene ozonolysis.

In the spectrum of P198 (Fig. 3a), fragments at $\mathrm{m} / \mathrm{z}, 153.1286$ and 179.1081 correspond to losses of $\mathrm{CO}_{2}$ and $\mathrm{H}_{2} \mathrm{O}$, respectively, from the quasi-molecular ion $\left([\mathrm{M}-\mathrm{H}]^{-}\right.$, $\mathrm{m} / \mathrm{z}$ 197.1188), indicating the presence of a carboxylic acid functional group. Compared to the two oxygen atoms in the identified carboxylic acid group, the molecular formula 
Table 2. Product labels, molecular formulas, oxygen-to-carbon elemental ratios (O:C), product reaction generation, estimated saturation vapor pressures $P_{\mathrm{vap}}$, and estimated saturation vapor concentrations $C^{*}$ of molecules produced by the dark ozonolysis of $\beta$-caryophyllene and as detected in the present study. Saturation vapor pressures were estimated using the SPARC on-line calculator (http://sparc.chem.uga. edu/sparc/) (Hilal et al., 2003). Table entries also include products as labelled by other conventions, including terpene nomenclature (Larsen et al., 1998), the IUPAC system (ACD/Labs, 2010), and that of Winterhalter et al. (2009).

\begin{tabular}{|c|c|c|c|c|c|c|c|c|}
\hline Product & Formula & Terpene nomenclature (Larsen et al., 1998) & $\begin{array}{l}\text { IUPAC nomenclature } \\
(\mathrm{ACD} / \text { Labs, 2010) }\end{array}$ & $\begin{array}{l}\text { Label in Winter- } \\
\text { halter et al. (2009) }\end{array}$ & $\mathrm{O}: \mathrm{C}$ & Generation & $P_{\text {vap }}(\mathrm{Pa})$ & $C^{*}\left(\mu \mathrm{g} / \mathrm{m}^{3}\right)$ \\
\hline P198 & $\mathrm{C}_{11} \mathrm{H}_{18} \mathrm{O}_{3}$ & - & $\begin{array}{l}\text { 3,3-dimethyl-2-(3- } \\
\text { oxobutyl)cyclobutanecarboxylic } \\
\text { acid }\end{array}$ & - & 0.27 & 2 & $1.2 \times 10^{-3}$ & $9.6 \times 10^{1}$ \\
\hline P236 & $\mathrm{C}_{15} \mathrm{H}_{24} \mathrm{O}_{2}$ & $\beta$-caryophyllon aldehyde & $\begin{array}{l}\text { 4-[3,3-dimethyl-2-(3- } \\
\text { oxobutyl)cyclobutyl]pent-4-enal }\end{array}$ & $\mathrm{P} 1$ & 0.13 & 1 & $4.2 \times 10^{-2}$ & $4.0 \times 10^{3}$ \\
\hline P238 & $\mathrm{C}_{14} \mathrm{H}_{22} \mathrm{O}_{3}$ & $\beta$-nocaryophyllon aldehyde & $\begin{array}{l}\text { 4-[3,3-dimethyl-2-(3- } \\
\text { oxobutyl)cyclobutyl]-4- } \\
\text { oxobutanal }\end{array}$ & $*^{\mathrm{a}}$ & 0.21 & 2 & $8.5 \times 10^{-3}$ & $8.2 \times 10^{2}$ \\
\hline $\mathrm{P} 252-1^{\mathrm{b}}$ & $\mathrm{C}_{15} \mathrm{H}_{24} \mathrm{O}_{3}$ & $\beta-14$-hydroxycaryophyllon aldehyde & $\begin{array}{l}\text { 4-[2-(4-hydroxy-3-oxobutyl)- } \\
\text { 3,3-dimethylcyclobutyl]pent-4- } \\
\text { enal }\end{array}$ & P5 & 0.20 & 1 & $4.3 \times 10^{-4}$ & $4.3 \times 10^{1}$ \\
\hline P252-2 & $\mathrm{C}_{15} \mathrm{H}_{24} \mathrm{O}_{3}$ & $\beta-5$-hydroxycaryophyllon aldehyde & $\begin{array}{l}\text { 4-[3,3-dimethyl-2-(3- } \\
\text { oxobutyl)cyclobutyl]-2- } \\
\text { hydroxypent-4-enal }\end{array}$ & P9 & 0.20 & 1 & $1.2 \times 10^{-3}$ & $1.2 \times 10^{2}$ \\
\hline P252-3 & $\mathrm{C}_{15} \mathrm{H}_{24} \mathrm{O}_{3}$ & $\beta-8$-hydroxycaryophyllon aldehyde & $\begin{array}{l}\text { 4-[2-(2-hydroxy-3-oxobutyl)- } \\
\text { 3,3-dimethylcyclobutyl]pent-4- } \\
\text { enal }\end{array}$ & $\mathrm{P} 8^{\mathrm{b}}$ & 0.20 & 1 & $1.6 \times 10^{-3}$ & $1.6 \times 10^{2}$ \\
\hline P252-4 & $\mathrm{C}_{14} \mathrm{H}_{20} \mathrm{O}_{4}$ & - & $\begin{array}{l}\text { 3-(4-acetyl-7,7-dimethyl-3- } \\
\text { oxabicyclo[4.2.0]oct-4-en-2- } \\
\text { yl)propanoic acid }\end{array}$ & - & 0.29 & 2 & $2.4 \times 10^{-4}$ & $2.4 \times 10^{1}$ \\
\hline P252-5 & $\mathrm{C}_{15} \mathrm{H}_{24} \mathrm{O}_{3}$ & $\beta$-caryophyllonic acid & $\begin{array}{l}\text { 4-[3,3-dimethyl-2-(3- } \\
\text { oxobutyl)cyclobutyl]pent-4- } \\
\text { enoic acid }\end{array}$ & P4 & 0.20 & 1 & $8.5 \times 10^{-6}$ & $8.7 \times 10^{-1}$ \\
\hline P254-1 & $\mathrm{C}_{14} \mathrm{H}_{22} \mathrm{O}_{4}$ & $\beta$-caryophyllinic acid & $\begin{array}{l}\text { 4-[2-(2-carboxyethyl)-3,3- } \\
\text { dimethylcyclobutyl]pent-4-enoic } \\
\text { acid }\end{array}$ & $\mathrm{P} 10$ & 0.29 & 1 & $1.3 \times 10^{-8}$ & $1.3 \times 10^{-3}$ \\
\hline P254-2 & $\mathrm{C}_{14} \mathrm{H}_{22} \mathrm{O}_{4}$ & $\beta-8$-hydroxynocaryophyllon aldehyde & $\begin{array}{l}\text { 4-[2-(2-hydroxy-3-oxobutyl)- } \\
\text { 3,3-dimethylcyclobutyl]-4- } \\
\text { oxobutanal }\end{array}$ & - & 0.29 & 2 & $2.9 \times 10^{-4}$ & $3.0 \times 10^{1}$ \\
\hline P254-3 & $\mathrm{C}_{14} \mathrm{H}_{22} \mathrm{O}_{4}$ & $\beta-5$-hydroxynocaryophyllon aldehyde & $\begin{array}{l}\text { 4-[3,3-dimethyl-2-(3- } \\
\text { oxobutyl)cyclobutyl]-2-hydroxy- } \\
\text { 4-oxobutanal }\end{array}$ & - & 0.29 & 2 & $3.1 \times 10^{-4}$ & $3.2 \times 10^{1}$ \\
\hline P270-1 & $\mathrm{C}_{14} \mathrm{H}_{22} \mathrm{O}_{5}$ & $\beta-4-$ hydroxynocaryophyllonic acid & $\begin{array}{l}\text { 4-[3,3-dimethyl-2-(3- } \\
\text { oxobutyl)cyclobutyl]-3-hydroxy- } \\
\text { 4-oxobutanoic acid }\end{array}$ & - & 0.36 & 2 & $6.2 \times 10^{-8}$ & $6.8 \times 10^{-3}$ \\
\hline P270-2 & $\mathrm{C}_{14} \mathrm{H}_{22} \mathrm{O}_{5}$ & $\beta-4,8$-dihydroxynocaryophyllon aldehyde & $\begin{array}{l}\text { 3-hydroxy-4-[2-(2- } \\
\text { hydroxy-3-oxobutyl)-3,3- } \\
\text { dimethylcyclobutyl]-4- } \\
\text { oxobutanal }\end{array}$ & - & 0.36 & 2 & $3.8 \times 10^{-6}$ & $4.1 \times 10^{-1}$ \\
\hline P270-3 & $\mathrm{C}_{14} \mathrm{H}_{22} \mathrm{O}_{5}$ & $\beta-4,5$-dihydroxynocaryophyllon aldehyde & $\begin{array}{l}\text { 4-[3,3-dimethyl-2-(3- } \\
\text { oxobutyl)cyclobutyl]-2,3- } \\
\text { dihydroxy-4-oxobutanal }\end{array}$ & - & 0.36 & 2 & $7.3 \times 10^{-6}$ & $8.0 \times 10^{-1}$ \\
\hline P302 & $\mathrm{C}_{14} \mathrm{H}_{22} \mathrm{O}_{7}$ & - & $\begin{array}{l}\text { 2,3-dihydroxy-4-[2-(4- } \\
\text { hydroxy-3-oxobutyl)-3,3- } \\
\text { dimethylcyclobutyl]-4- } \\
\text { oxobutanoic acid }\end{array}$ & - & 0.50 & 2 & $3.3 \times 10^{-13}$ & $4.0 \times 10^{-8}$ \\
\hline
\end{tabular}

a listed but not labeled.

b see Table 5 of Winterhalteret al. (2009); version displayed in Fig. 11 therein is not accurate (R. Winterhalter, personal communication, 2010).

of $\mathrm{C}_{11} \mathrm{H}_{18} \mathrm{O}_{3}$ indicates the presence of one further oxygen atom. The double-bond equivalency (DBE) is a quantity that includes both double bonds and rings, and the DBE of $\mathrm{C}_{11} \mathrm{H}_{18} \mathrm{O}_{3}$ is 3 , suggesting, in addition to the carboxylic group, the further presence of one ring and a third oxygen atom as a carbonyl group.

For the spectrum of P252-4 (Fig. 3b), the fragment at $m / z 207.1390$ forms by loss of $44 \mathrm{Da}\left(\mathrm{CO}_{2}\right)$ from the quasimolecular ion $\left([\mathrm{M}-\mathrm{H}]^{-}, m / z, 251.1295\right)$, indicating a carboxylic moiety. Loss of $\mathrm{H}_{2} \mathrm{O}$ from the quasi-molecular ion forms a fragment at $\mathrm{m} / \mathrm{z} 233.1190$ and can occur from either a carboxylic or a carbonyl group. The ion peak at $m / z 165.1292$ suggests a consecutive loss of $\mathrm{C}_{2} \mathrm{H}_{2} \mathrm{O}$ from $m / z 207.1390\left(\left[\mathrm{M}-\mathrm{H}-\mathrm{CO}_{2}\right]^{-}\right)$, indicating that a carbonyl group is present in P252-4 as an acetyl group. The fragment at $m / z 149.0974$ is believed to form via the cleavage of the ring structure.

In the fragmentation spectrum of P302 (Fig. 3c), fragments at 103.0040 and 197.1185 correspond to $\mathrm{C}_{3} \mathrm{H}_{3} \mathrm{O}_{4}^{-}$and $\mathrm{C}_{11} \mathrm{H}_{17} \mathrm{O}_{3}^{-}$, respectively. The fragment $\mathrm{C}_{3} \mathrm{H}_{3} \mathrm{O}_{4}^{-}$is proposed 


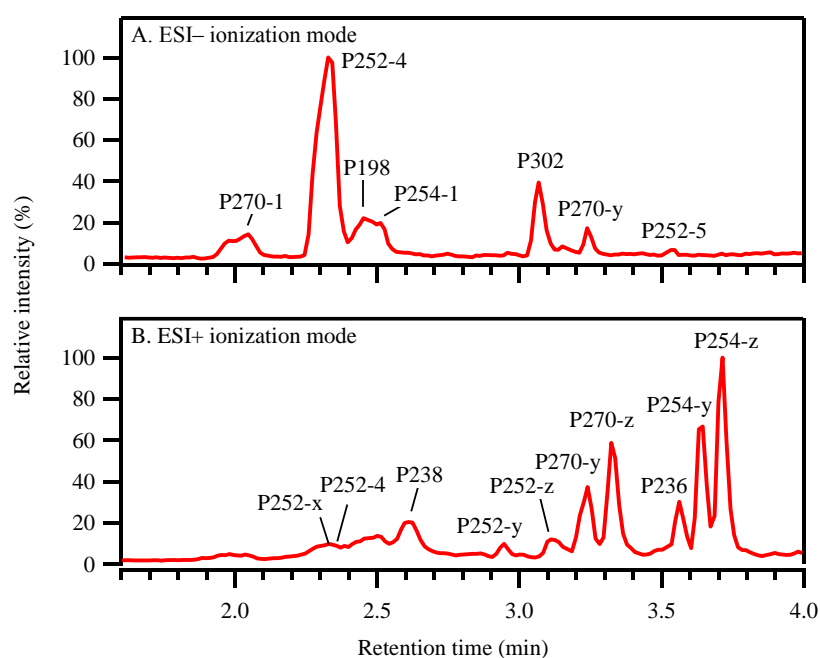

Fig. 2. Chromatograms of the particle-phase products of the dark ozonolysis of $\beta$-caryophyllene, as obtained by UPLC-ToF-MS with electrospray ionization (ESI). Ordinate values are the sum of measured ion intensities. Panels (A) and (B) show the results from analysis in ESI- and ESI+ modes, respectively. Product labels are as described in the caption of Fig. 1. Labels such as "P252- $x$ ", "P252$y$ ", and "P252- $z$ " have ambiguous molecular assignments, with $x$, $y$, and $z$ representing a permutation of 1,2 , and 3 .

to form from the $\alpha, \beta$-dihydroxyl- $\gamma$-keto-carboxlyic moiety (Fig. 3c) via a McLafferty-type rearrangement (Grossert et al., 2006). Loss of $44 \mathrm{Da}\left(\mathrm{CO}_{2}\right)$ is not observed in the spectrum, possibly due to the presence of a hydroxyl group in the $\alpha$-position to the carboxylic group (Bandu et al., 2004). Instead, consecutive losses of $2 \mathrm{H}_{2} \mathrm{O}$ and $1 \mathrm{HCHO}$, a phenomenon which is common in carboxylic acids having multiple hydroxyl and carbonyl groups, result in an ion peak at $m / z 235.0954$ (formula $\mathrm{C}_{13} \mathrm{H}_{15} \mathrm{O}_{4}^{-}$) (Warscheid and Hoffmann, 2001).

A comparison of our product assignments with those of Winterhalter et al. (2009) can be found in Table 2. Winterhalter et al. (2009) identified 14 products, labelled P1 through $\mathrm{P} 12 \mathrm{~b}$. We have in common 6 products $(\mathrm{P} 1, \mathrm{P} 4, \mathrm{P} 5, \mathrm{P} 8, \mathrm{P} 9$, and $\mathrm{P} 10)$. Of the remaining 8 products, two (P2a and $\mathrm{P} 2 \mathrm{~b}$ ) are excluded from further discussion because these esters are believed to form at low yields (Nguyen et al., 2009), suggesting that their presence is below our limit of detection. The four first-generation products $\mathrm{P} 3, \mathrm{P} 6, \mathrm{P} 7$, and $\mathrm{P} 11$ are anticipated based on the mechanism of Winterhalter et al. (2009) (cf. Fig. 11 therein), yet in our data ion peaks with molecular weights of 208 (P3), 250 (P6/P7), and 222 (P11) are not present, possibly due to low yields of those products (Nguyen et al., 2009) or alternatively due to our detection methods. The second-generation product $\mathrm{P} 12 \mathrm{~b}$ with molecular weight 210 is also not present in our data. On the other hand, compared to Winterhalter et al. (2009), our data summarized in Table 2 indicate eight additional second-generation products.
Some other structures reported in the literature were not observed by us. In particular, secondary ozonides were inferred from infrared spectra of gas-phase reaction products (Nguyen et al., 2009; Winterhalter et al., 2009). In our results, we did not observe any mass spectral feature of secondary ozonides in the particle-phase products. Possible explanations are several. First, the infrared signature of secondary ozonides and organic peroxides might be similar and difficult to discriminate from each other. Second, the unimolecular reaction forms an endo secondary ozonide $(1,2,4-$ trioxolane), which has an estimated vapor pressure of $0.34 \mathrm{~Pa}$ and should therefore remain largely in the gas phase. Third, the experimental conditions of low hydrocarbon concentrations and moderately high RH of our study do not favorbimolecular reactions that form high-molecular-weight secondary ozonides. Without any evidence in our data for their formation, we do not consider secondary ozonides further in our continuing discussion, yet we do not exclude the possibility of their formation.

\subsection{Product formation}

Mechanistic studies in the literature of $\beta$-caryophyllene ozonolysis have focused mainly on the first-generation products formed by reactions at the endo-cyclic double bond (Jaoui et al., 2003; Winterhalter et al., 2009). Product formation proceeds in large part along one of four reaction competing channels. The four channels are via (1) a stabilized Criegee intermediate (SCI), (2) a vinyl hydroperoxide (VHP), (3) isomerization (ISO), or (4) a dioxirane intermediate to esters or acids (ester channel). Section 6 of the supporting material describes each pathway in greater detail, and the reaction channels of $\beta$-caryophyllene ozonolysis that lead to the first-generation products shown in Fig. $1 \mathrm{~b}$ are illustrated in detail in Figs. S4, S5, and S6.

In the case of excess ozone, as in the present study, the first-generation products react further at the second (i.e., exocyclic) double bond. The proposed pathways that lead to the formation of the second-generation products detected in the particle phase are shown in Fig. 4. Ozonolysis of the firstgeneration product $\mathrm{P} 236$ along SCI, VHP, and ISO channels results in the second-generation products $\mathrm{P} 238, \mathrm{P} 252-4$, and P198, respectively (Scheme A). A detailed reaction scheme is given in Fig. S7. Ozonolysis of the first-generation products P252-2 and P252-3 via SCI and VHP channels forms the second-generation products P254-2, P254-3, P270-2, and P270-3 (Schemes B and C, respectively). A detailed reaction scheme is given in Fig. S8. The formation of the second-generation products $\mathrm{P} 270-1$ and $\mathrm{P} 302$ is proposed via VHP and ISO channels from P252-5 and P252-1, respectively (Schemes D and E, Fig. 4). Detailed reaction schemes are given in Figures S6. The mechanism of P302 formation (Scheme B, Fig. S6) follows multiple VHP or ISO channels to introduce several hydroxyl groups into the molecule. In 

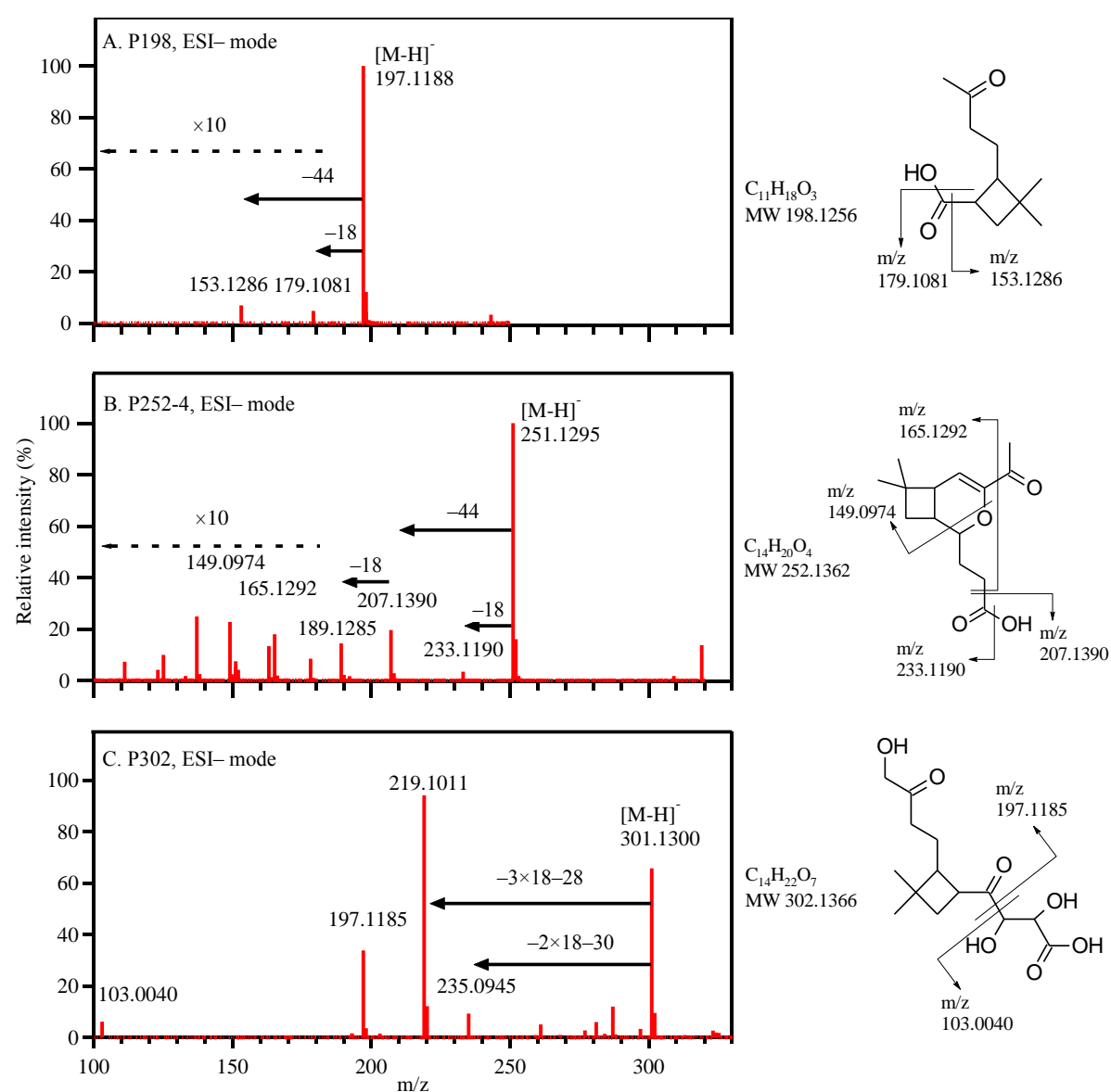

Fig. 3. Fragmentation mass spectra of particle-phase products not previously identified in the literature, including (A) P198, (B) P252-4, and (C) P302. Fragmentation spectra were obtained by increasing the "aperture 1" voltage of the ToF-MS from 5 to 25 V (Table S3), inducing in-source collision and dissociation. Fragmentation achieved in this way is comparable to that obtained by tandem-in-space techniques such as a triple quadrupole analyzer (Gerssen et al., 2008) and provides additional information for structural elucidation. Proposed structure and fragmentation points are shown to the right of each panel. Solid arrows in the main figures indicate the fragmentation pathways that yield the observed ion peaks. Loss of $\mathrm{H}_{2} \mathrm{O}$ is indicated by -18 , and loss of $\mathrm{CO}_{2}$ corresponds to -44 . Dashed arrows indicate regions in which the signal intensities are multiplied by a factor of 10 .

addition, the six identified first-generation products can in principle form many more second-generation products than represented by the schemes of Fig. 4; only pathways to observed products are shown in the figure. Pathways to other products might occur in low yields (Nguyen et al., 2009), some of the products might not partition favorably to the particle phase, or alternatively some of those products might not be detected by our methods.

The sum of the surrogate concentrations measured by the UPLC-MS method varies from two to five times higher than that measured by the HR-ToF-AMS for different experiments. The surrogate approach using a pinic-acid and pinonic-acid equivalency basis for the UPLC-MS analysis is believed to introduce an error of $\pm 30 \%$ (Jaoui et al., 2003). In addition, a positive sampling artifact by filter methods can be as high as 60\% (Kim et al., 2001; Kirchstetter et al., 2001; Mader and Pankow, 2001). Variance up to a factor of ten between the UPLC-MS and HR-ToF-AMS can be largely accounted for by these two types of systematic errors. The conclusion, given that $(2$ to 5 ) $<10$, is that a substantial fraction of the total organic particle mass concentration is represented by the 15 identified products.

\subsection{Product volatilities}

The reversible partitioning of an organic molecule between the gas and particle phases of an aerosol is regulated to first approximation by the molecule's saturation vapor pressure $P_{\text {vap }}$ (Seinfeld and Pankow, 2003). In this study, we used SPARC Performs Automated Reasoning in Chemistry (SPARC) (Hilal et al., 2003) to estimate vapor pressures for molecular structures. Results are listed in Table 2. Saturation vapor concentrations $C^{*}$ are also listed in Table 2 using the ideal gas law at $298 \mathrm{~K}$ to convert from vapor pressures. In 


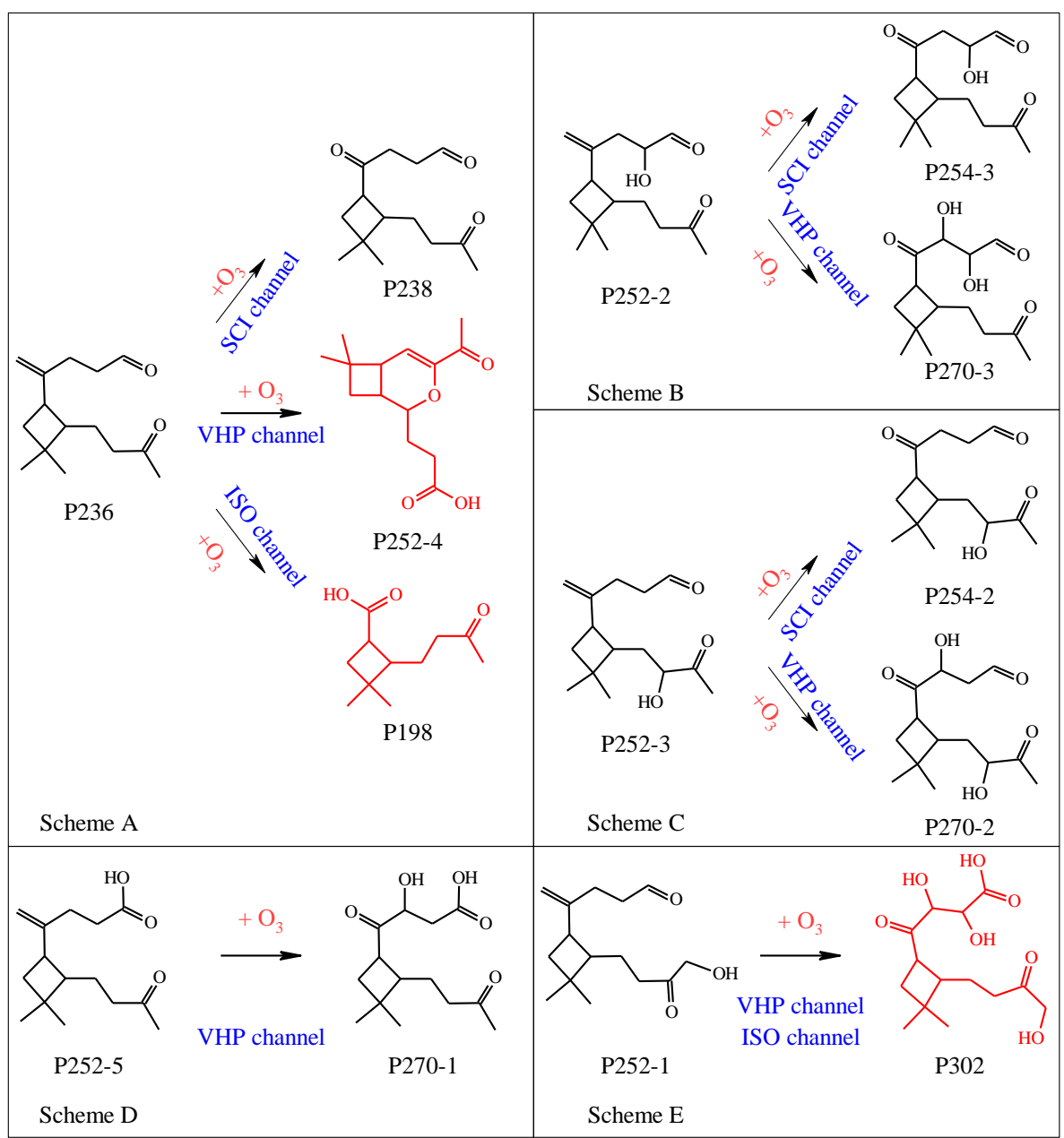

Fig. 4. Ozonolysis pathways from first- to second-generation products. The three new products identified in this study are shown in red. Reaction channels (blue): SCI, stabilization of Criegee intermediate (CI) by collision with gas-phase molecules (M) and subsequent reaction with $\mathrm{H}_{2} \mathrm{O}$ followed by loss of $\mathrm{H}_{2} \mathrm{O}_{2}$ (cf. Fig. S4); VHP, formation and subsequent rearrangement of a vinyl hydroperoxide (cf. Fig. S4); and ISO, formation and subsequent isomerization of a product (cf. Fig. S5).

Fig. 5, values of $P_{\text {vap }}$ and $C^{*}$ are plotted against the O:C elemental ratios of $\beta$-caryophyllene and its ozonolysis products. Black lines show the chemical links from first- to secondgeneration products.

Because estimates of saturation vapor pressures can vary significantly depending on the method used (Barley and McFiggans, 2010), we also used the group contribution method SIMPOL for comparison (Pankow and Asher, 2008). The estimates of vapor pressure by these methods can differ by two orders of magnitude. Booth et al. (2010) emphasize that these methods are especially uncertain for multi-functional organic molecules in which the effects of hydrogen-bonding are present but not fully accounted for. Nevertheless, Fig. 5 represents 15 orders of magnitude. Hereafter, we restrict ourselves to conclusions that can be reached keeping in mind the uncertainties of the vapor-pressure estimates.
The first-generation product P254-1 ( $\beta$-caryophyllinic acid, $C^{*}=1.3 \times 10^{-3} \mu \mathrm{g} \mathrm{m}^{-3}$ ) is expected to have a strong presence in the particle phase and has been used for ambient samples as an atmospheric tracer of $\beta$-caryophyllene SOA (Jaoui et al., 2007; Hu et al., 2008). Three of the six first-generation products (i.e., P236, P252-2, and P2523 ) have relatively high saturation vapor concentrations (i.e., $C^{*}>100 \mu \mathrm{g} \mathrm{m}^{-3}$ ). They are therefore predicted to partition dominantly to the gas phase and be minor contributors to the particle phase for the organic particle mass concentrations of 0.5 to $30 \mu \mathrm{g} \mathrm{m}^{-3}$ employed in the present study. Even with their high $C^{*}$ values, however, these products still do partition to some extent to the particle phase, as evidenced in this study's measurements and as explained thermodynamically by the effects of an organic mixture on the activities of the constituent organic species (i.e., having the effect of reducing the vapor pressure of individual species) (Pankow, 1994). 


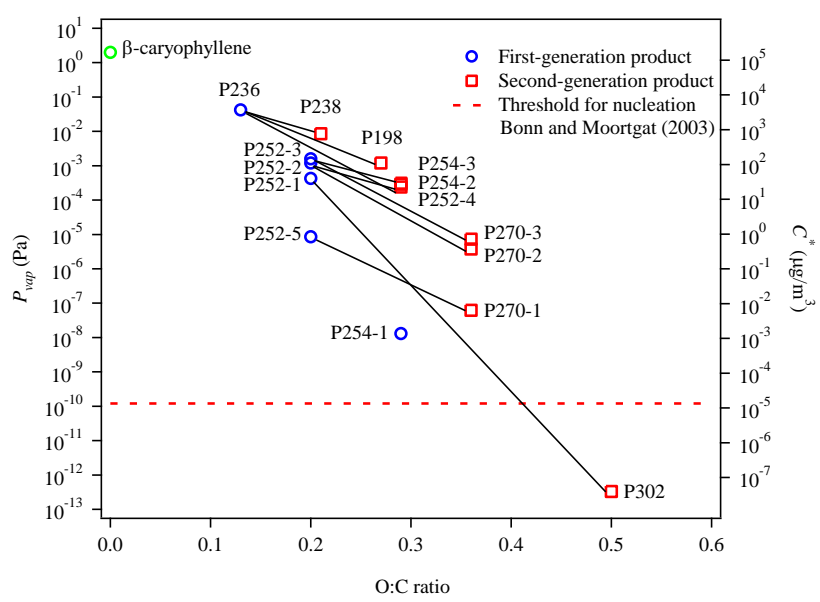

Fig. 5. Estimated saturation vapor pressures $P_{\text {vap }}$ and saturation vapor concentrations $C^{*}$ plotted against the O:C elemental ratio of $\beta$-caryophyllene and its ozonolysis products. The dashed red line is the threshold saturation vapor pressure at which new particle formation occurs, as suggested by Bonn and Moortgat (2003). Black lines connect first-generation products to their second-generation counterparts. Although each first-generation product can be expected to produce multiple possible second-generation products (e.g., such as three products from P236), for clarity of presentation only those products actually observed in the particle phase on the basis of the present study's results are represented in the figure.

In comparison to two first-generation products of low volatility (P252-5 and P254-1), four second-generation products (P270-1, P270-2, P270-3, and P302) have $C^{*}<1 \mu \mathrm{g} \mathrm{m}^{-3}$, and these products are therefore expected to partition mainly to the particle phase.

The mass fractions of first- and second-generation products are shown in Fig. 6 for increasing organic particle mass concentration from 0.5 to $30 \mu \mathrm{g} \mathrm{m}^{-3}$. The mass fractions are calculated by dividing the individual mass concentrations of the products by the sum of their concentrations, all as determined by the UPLC-MS method using the surrogate approach. Across this range, the second-generation products are dominant by a factor of approximately 10 . Toward the low-end of the concentration range, the secondgeneration products are increasingly dominant. This observation is consistent with the representation in Fig. 5 that second-generation products are typically of lower volatility than their first-generation precursors.

Bonn and Moortgat (2003) suggested that sesquiterpeneozone reactions might initiate new particle formation in boreal forests. They estimated a threshold saturation vapor pressure of $1.2 \times 10^{-10} \mathrm{~Pa}$ for the nucleating compounds, as represented by the red dashed line in Fig. 5. The product P302 has an estimated saturation vapor pressure of $3.3 \times 10^{-13} \mathrm{~Pa}$, making this product a candidate contributor to new particle formation in the atmosphere.

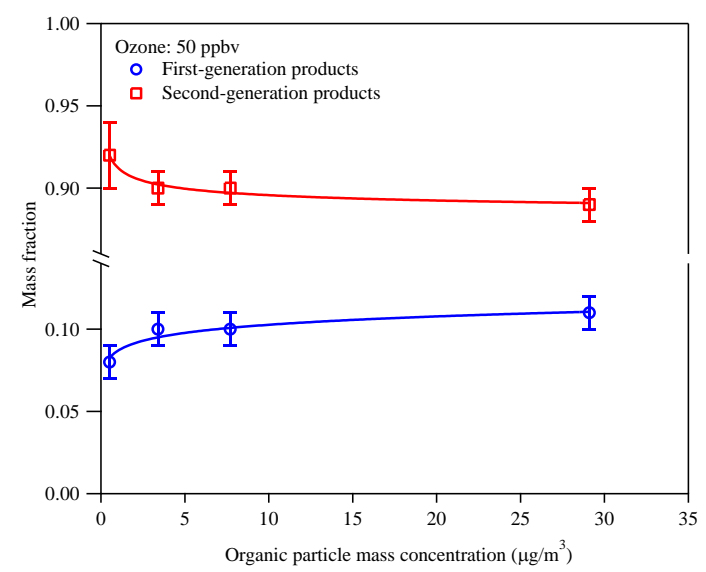

Fig. 6. Mass fractions of first- (blue) and second-generation (red) products for increasing organic particle mass concentration. The abscissa of organic particle mass concentration was measured using the AMS. The ordinate of mass fraction represents the mass concentrations of the first- and second-generation products divided by the sum of mass concentrations, all as measured by UPLC-MS. In these experiments, the $\beta$-caryophyllene concentrations varied from 1.7 to 46.4 ppbv, generating particle organic mass concentrations from the low to high values represented in the figure. The ozone concentration was 50 ppbv. Error bars represent \pm 1 standard deviation of the mass percentages of three replicate experiments. Lines are shown to guide the eye.

\section{Conclusions}

The results of this study suggest that most first-generation products of sesquiterpene ozonolysis, to the extent that $\beta$ caryophyllene is representative of that class, are sufficiently volatile to remain in the gas phase. These products, however, are still reactive toward ozone. Further oxidation products are formed by the ozonolysis of the second double bond, and the present study's results show that many of these second-generation products partition to the particle phase. The results suggest that for most of the troposphere, specifically at times and locations for which ozonerich conditions prevail with respect to sesquiterpene concentrations, second-generation gas-phase chemistry is expected to drive the sesquiterpene contribution to oxygenated organic material and its subsequent appearance in the particle phase. Some of these products also have very low volatilities, as evidenced in a monomeric second-generation product P302 having 7 oxygen atoms that was identified in this study. Its estimated saturation vapor concentration, if accurate, suggests that it is a candidate compound for new particle formation in forested environments. The secondgeneration compounds also have multiple polar functional groups (mainly $\mathrm{OH}, \mathrm{C}=\mathrm{O}$, and $\mathrm{COOH}$ ) that favorably interact with water, suggesting that organic material formed under first-generation conditions (e.g., in a laboratory setting) has significantly different hygroscopic properties, including as 
related to cloud activation, than organic material formed under atmospherically relevant second-generation conditions. The importance of accurately reflecting atmospheric conditions in laboratory experiments has previously been emphasized for the influence of organic particle mass concentration on CCN activity and particle mass yield (Shilling et al., 2008; King et al., 2009; Shilling et al., 2009).

\section{Supplement related to this article is available online at: http://www.atmos-chem-phys.net/11/121/2011/ acp-11-121-2011-supplement.pdf.}

Acknowledgements. This material is based upon work supported by the Office of Science (BES), US Department of Energy, Grant No. DE-FG02-08ER64529. YJL gratefully acknowledges support from the Hong Kong University of Science and Technology Overseas Research Award and the Research Grants Council of the Hong Kong Special Administrative Region, China (Project No. 610909). QC acknowledges support from the NASA Earth and Space Science Fellowship. The authors thank Amanda Mifflin, Mackenzie Smith, and Mikinori Kuwata for their support and valuable suggestions as well as Karena McKinney for gas-phase measurements carried out using an Ionic on proton-transfer-reaction mass spectrometer.

Edited by: G. McFiggans

\section{References}

ACD/Labs: ACD/ChemSketch, in, 12.01 ed., Advanced Chemistry Development, Inc., Toronto, ON, Canada, 2010.

Asa-Awuku, A., Engelhart, G. J., Lee, B. H., Pandis, S. N., and Nenes, A.: Relating CCN activity, volatility, and droplet growth kinetics of beta-caryophyllene secondary organic aerosol, Atmos. Chem. Phys., 9, 795-812, doi:10.5194/acp-9-795-2009, 2009.

Bandu, M. L., Watkins, K. R., Bretthauer, M. L., Moore, C. A., and Desaire, H.: Prediction of MS/MS data. 1. A focus on pharmaceuticals containing carboxylic acids, Anal. Chem., 76, 17461753, 2004.

Barley, M. H., and McFiggans, G.: The critical assessment of vapour pressure estimation methods for use in modelling the formation of atmospheric organic aerosol, Atmos. Chem. Phys., 10, 749-767, doi:10.5194/acp-10-749-2010, 2010.

Bonn, B. and Moortgat, G. K.: Sesquiterpene ozonolysis: Origin of atmospheric new particle formation from biogenic hydrocarbons, Geophys. Res. Lett., 30, 1585, doi:1510.1029/2003g1017000, 2003.

Booth, A. M., Barley, M. H., Topping, D. O., McFiggans, G., Garforth, A., and Percival, C. J.: Solid state and sub-cooled liquid vapour pressures of substituted dicarboxylic acids using Knudsen Effusion Mass Spectrometry (KEMS) and Differential Scanning Calorimetry, Atmos. Chem. Phys., 10, 4879-4892, doi:10.5194/acp-10-4879-2010, 2010.

Ciccioli, P., Brancaleoni, E., Frattoni, M., Di Palo, V., Valentini, R., Tirone, G., Seufert, G., Bertin, N., Hansen, U., Csiky, O., Lenz, R., and Sharma, M.: Emission of reactive terpene compounds from orange orchards and their removal by within- canopy processes, J. Geophys. Res.-Atmos., 104, 8077-8094, doi:8010.1029/1998JD100026, 1999.

DeCarlo, P. F., Kimmel, J. R., Trimborn, A., Northway, M. J., Jayne, J. T., Aiken, A. C., Gonin, M., Fuhrer, K., Horvath, T., Docherty, K. S., Worsnop, D. R., and Jimenez, J. L.: Field-deployable, high-resolution, time-of-flight aerosol mass spectrometer, Anal. Chem., 78, 8281-8289, 2006.

Duhl, T. R., Helmig, D., and Guenther, A.: Sesquiterpene emissions from vegetation: a review, Biogeosciences, 5, 761-777, doi:10.5194/bg-5-761-2008, 2008.

Fiore, A., Jacob, D. J., Liu, H., Yantosca, R. M., Fairlie, T. D., and Li, Q.: Variability in surface ozone background over the United States: Implications for air quality policy, J. Geophys. Res., 108, 4787, doi:4710.1029/2003jd003855, 2003.

Gao, S., Keywood, M., Ng, N. L., Surratt, J., Varutbangkul, V., Bahreini, R., Flagan, R. C., and Seinfeld, J. H.: Low-molecularweight and oligomeric components in secondary organic aerosol from the ozonolysis of cycloalkenes and alpha-pinene, J. Phys. Chem. A, 108, 10147-10164, 2004.

Gerssen, A., Mulder, P., van Rhijn, H., and de Boer, J.: Mass spectrometric analysis of the marine lipophilic biotoxins pectenotoxin- 2 and okadaic acid by four different types of mass spectrometers, J. Mass Spectrom., 43, 1140-1147, 2008.

Glasius, M., Duane, M., and Larsen, B. R.: Determination of polar terpene oxidation products in aerosols by liquid chromatography-ion trap mass spectrometry, J. Chromatogr. A, 833, 121-135, 1999.

Griffin, R. J., Cocker, D. R., Flagan, R. C., and Seinfeld, J. H.: Organic aerosol formation from the oxidation of biogenic hydrocarbons, J. Geophys. Res.-Atmos., 104, 3555-3567, doi:3510.1029/1998JD100049, 1999.

Grosjean, D., Williams, E. L., Grosjean, E., Andino, J. M., and Seinfeld, J. H.: Atmospheric oxidation of biogenic hydrocarbonsreaction of ozone with beta-pinene, d-limonene and transcaryophyllene, Environ. Sci. Technol., 27, 2754-2758, 1993.

Grossert, J. S., Cook, M. C., and White, R. L.: The influence of structural features on facile McLafferty-type, even-electron rearrangements in tandem mass spectra of carboxylate anions, Rapid Commun. Mass Spectrum, 20, 1511-1516, 2006.

Hallquist, M., Wenger, J. C., Baltensperger, U., Rudich, Y., Simpson, D., Claeys, M., Dommen, J., Donahue, N. M., George, C., Goldstein, A. H., Hamilton, J. F., Herrmann, H., Hoffmann, T., Iinuma, Y., Jang, M., Jenkin, M. E., Jimenez, J. L., KiendlerScharr, A., Maenhaut, W., McFiggans, G., Mentel, T. F., Monod, A., Prevot, A. S. H., Seinfeld, J. H., Surratt, J. D., Szmigielski, R., and Wildt, J.: The formation, properties and impact of secondary organic aerosol: current and emerging issues, Atmos. Chem. Phys., 9, 5155-5236, 2009.

Hartz, K. E. H., Rosenorn, T., Ferchak, S. R., Raymond, T. M., Bilde, M., Donahue, N. M., and Pandis, S. N.: Cloud condensation nuclei activation of monoterpene and sesquiterpene secondary organic aerosol, J. Geophys. Res.-Atmos., 110, D14208, doi:14210.11029/12004jd005754, 2005.

Helmig, D., Balsley, B., Davis, K., Kuck, L. R., Jensen, M., Bognar, J., Smith, T., Arrieta, R. V., Rodriguez, R., and Birks, J. W. Vertical profiling and determination of landscape fluxes of biogenic nonmethane hydrocarbons within the planetary boundary layer in the Peruvian Amazon, J. Geophys. Res.-Atmos., 103, 25519-25532, doi:25510.21029/25598JD01023, 1998. 
Hilal, S. H., Karickhoff, S. W., and Carreira, L. A.: Prediction of the vapor pressure boiling point, heat of vaporization and diffusion coefficient of organic compounds, QSAR Comb. Sci., 22, 565$574,2003$.

Hoffmann, T., Odum, J. R., Bowman, F., Collins, D., Klockow, D., Flagan, R. C., and Seinfeld, J. H.: Formation of organic aerosols from the oxidation of biogenic hydrocarbons, J. Atmos. Chem., 26, 189-222, 1997.

Hu, D., Bian, Q., Li, T. W. Y., Lau, A. K. H., and Yu, J. Z.: Contributions of isoprene, monoterpenes, beta-caryophyllene, and toluene to secondary organic aerosols in Hong Kong during the summer of 2006, J. Geophys. Res. -Atmos., 113, D22206, doi:22210.21029/22008jd010437, 2008.

Jaoui, M., Leungsakul, S., and Kamens, R. M.: Gas and particle products distribution from the reaction of beta-caryophyllene with ozone, J. Atmos. Chem., 45, 261-287, 2003.

Jaoui, M., Lewandowski, M., Kleindienst, T. E., Offenberg, J. H., and Edney, E. O.: beta-caryophyllinic acid: An atmospheric tracer for beta-caryophyllene secondary organic aerosol, Geophys. Res. Lett., 34, L05816, doi:05810.01029/02006g1028827, 2007.

Kanawati, B., Herrmann, F., Joniec, S., Winterhalter, R., and Moortgat, G. K.: Mass spectrometric characterization of betacaryophyllene ozonolysis products in the aerosol studied using an electrospray triple quadrupole and time-of-flight analyzer hybrid system and density functional theory, Rapid Commun. Mass Spectrum, 22, 165-186, 2008.

Kim, B. M., Cassmassi, J., Hogo, H., and Zeldin, M. D.: Positive organic carbon artifacts on filter medium during $\mathrm{PM}_{2.5}$ sampling in the South Coast Air Basin, Aerosol Sci. Technol., 34, 35-41, 2001.

King, S. M., Rosenoern, T., Shilling, J. E., Chen, Q., and Martin, S. T.: Increased cloud activation potential of secondary organic aerosol for atmospheric mass loadings, Atmos. Chem. Phys., 9, 2959-2971, doi:10.5194/acp-9-2959-2009, 2009.

Kirchstetter, T. W., Corrigan, C. E., and Novakov, T.: Laboratory and field investigation of the adsorption of gaseous organic compounds onto quartz filters, Atmos. Environ., 35, 1663-1671, 2001.

Kroll, J. H. and Seinfeld, J. H.: Chemistry of secondary organic aerosol: formation and evolution of low-volatility organics in the atmosphere, Atmos. Environ., 42, 3593-3624, 2008.

Larsen, B. R., Lahaniati, M., Calogirou, A., and Kotzias, D.: Atmospheric oxidation products of terpenes: A new nomenclature, Chemosphere, 37, 1207-1220, 1998.

Lee, A., Goldstein, A. H., Kroll, J. H., Ng, N. L., Varutbangkul, V., Flagan, R. C., and Seinfeld, J. H.: Gas-phase products and secondary aerosol yields from the photooxidation of 16 different terpenes, J. Geophys. Res. -Atmos., 111, D17305, doi:17310.11029/12006jd007050, 2006.

Mader, B. T. and Pankow, J. F.: Gas/solid partitioning of semivolatile organic compounds (SOCs) to air filters. 3. An analysis of gas adsorption artifacts in measurements of atmospheric SOCs and organic carbon (OC) when using Teflon membrane filters and quartz fiber filters, Environ. Sci. Technol., 35, 34223432,2001

Martin, S. T., Andreae, M. O., Artaxo, P., Baumgardner, D., Chen, Q., Goldstein, A. H., Guenther, A., Heald, C. L., MayolBracero, O. L., McMurry, P. H., Pauliquevis, T., Poschl, U.,
Prather, K. A., Roberts, G. C., Saleska, S. R., Dias, M. A. S., Spracklen, D. V., Swietlicki, E., and Trebs, I.: Sources and properties of Amazonian aerosol particles, Rev. Geophys., 48, 2002, doi:10.1029/2008rg000280, 2010.

Ng, N. L., Kroll, J. H., Keywood, M. D., Bahreini, R., Varutbangkul, V., Flagan, R. C., Seinfeld, J. H., Lee, A., and Goldstein, A. H.: Contribution of first- versus second-generation products to secondary organic aerosols formed in the oxidation of biogenic hydrocarbons, Environ. Sci. Technol., 40, 2283-2297, 2006.

Nguyen, T. L., Winterhalter, R., Moortgat, G., Kanawati, B., Peeters, J., and Vereecken, L.: The gas-phase ozonolysis of beta-caryophyllene $\left(\mathrm{C}_{15} \mathrm{H}_{24}\right)$. Part II: A theoretical study, Phys. Chem. Chem. Phys., 11, 4173-4183, 2009.

Pankow, J. F.: An absorption model of the gas aerosol partitioning involved in the formation of secondary organic aerosol, Atmos. Environ., 28, 189-193, 1994.

Pankow, J. F. and Asher, W. E.: SIMPOL.1: a simple group contribution method for predicting vapor pressures and enthalpies of vaporization of multifunctional organic compounds, Atmos. Chem. Phys., 8, 2773-2796, doi:10.5194/acp-8-2773-2008, 2008.

Parshintsev, J., Nurmi, J., Kilpelainen, I., Hartonen, K., Kulmala, M., and Riekkola, M. L.: Preparation of beta-caryophyllene oxidation products and their determination in ambient aerosol samples, Anal. Bioanal. Chem., 390, 913-919, 2008.

Pio, C., Alves, C., and Duarte, A.: Organic components of aerosols in a forested area of central Greece, Atmos. Environ., 35, 389401, 2001.

Seinfeld, J. H. and Pankow, J. F.: Organic atmospheric particulate material, Annu. Rev. Phys. Chem., 54, 121-140, 2003.

Shilling, J. E., Chen, Q., King, S. M., Rosenoern, T., Kroll, J. H., Worsnop, D. R., McKinney, K. A., and Martin, S. T.: Particle mass yield in secondary organic aerosol formed by the dark ozonolysis of alpha-pinene, Atmos. Chem. Phys., 8, 2073-2088, doi:10.5194/acp-8-2073-2008, 2008.

Shilling, J. E., Chen, Q., King, S. M., Rosenoern, T., Kroll, J. H., Worsnop, D. R., DeCarlo, P. F., Aiken, A. C., Sueper, D., Jimenez, J. L., and Martin, S. T.: Loading-dependent elemental composition of alpha-pinene SOA particles, Atmos. Chem. Phys., 9, 771-782, doi:10.5194/acp-9-771-2009, 2009.

Shu, Y. H. and Atkinson, R.: Atmospheric lifetimes and fates of a series of sesquiterpenes, J. Geophys. Res.-Atmos., 100, 72757281, doi:10.1029/7295JD00368, 1995.

Solomon, P., Cowling, E., Hidy, G., and Furiness, C.: Comparison of scientific findings from major ozone field studies in North America and Europe, Atmos. Environ., 34, 1885-1920, 2000.

Warscheid, B. and Hoffmann, T.: Structural elucidation of monoterpene oxidation products by ion trap fragmentation using on-line atmospheric pressure chemical ionisation mass spectrometry in the negative ion mode, Rapid Commun. Mass Spectrum, 15, 2259-2272, 2001.

Winterhalter, R., Herrmann, F., Kanawati, B., Nguyen, T. L., Peeters, J., Vereecken, L., and Moortgat, G. K.: The gas-phase ozonolysis of beta-caryophyllene $\left(\mathrm{C}_{15} \mathrm{H}_{24}\right)$. Part I: an experimental study, Phys. Chem. Chem. Phys., 11, 4152-4172, 2009. 